\title{
Application of a novel biopolymer to enhance oil recovery
}

\author{
Changhong Gao ${ }^{1}$
}

Received: 12 April 2015/Accepted: 29 October 2015/Published online: 13 November 2015

(c) The Author(s) 2015. This article is published with open access at Springerlink.com

\begin{abstract}
Schizophyllan is a biopolymer used as a skin care product and immunity enhancement agent. This short communication studies the rheology of schizophyllan solution under high salinity and high temperature. Experiments show schizophyllan maintains high viscosity under very high salinity. The loss of viscosity is insignificant under high temperature up to $100{ }^{\circ} \mathrm{C}$. The impressive stability of schizophyllan under high temperature and high salinity renders its potential to enhance oil recovery in oil and gas industry. A field pilot was carried out since 2012 . Field results indicate the injection of schizophyllan solution into oil strata leads to improved oil production.
\end{abstract}

Keywords Biopolymer - Oil recovery $\cdot$ Salinity $\cdot$ Field trial

\section{Introduction}

In most oil fields, water is injected into underground reservoir rocks to maintain reservoir pressure and sweep oil into production wells. This operation is referred to as water flooding. But, operation only recovers less than $50 \%$ original oil in place (OOIP). Researchers have developed various methods to enhance oil recovery (EOR), including thermal methods, chemical methods, and gas injection (Lake 2010; Gao 2011).

Certain polymers, such as partially hydrolyzed polyacrylamide (HPAM) and Xanthan gum, proved effective in

Changhong Gao

237184689@QQ.com

1 Sinopec Shengli E\&P Research Center, Dongying 257000, Shandong, China improving oil recovery (Sheng 2010). Injection of polymer solution into reservoirs is named polymer flooding. Largescale polymer flooding projects have been successfully carried out in China since 1990s (Gao et al. 2014). This method was also applied in Angola and Brazil (Morel et al. 2010).

For commercial EOR projects, HPAM is the most commonly injected polymer. However, HPAM is rather sensitive to salinity and temperature (Gao 2013, 2014). As a result, HPAM severely degrades when injected into high temperature reservoirs containing high salinity water. This indeed limits the industrial adoption of polymer EOR method.

The oil and gas industry has been actively searching for a polymer that can tolerate high salinity and high temperature. In recent years, biopolymers have attracted the attention of petroleum industry (Xu et al. 2014; Gao 2015). Schizophyllan (SPG) is a neutral exopolysaccharide produced by the fungus Schizophyllum commune Fries. Its chemical structure is identical to scleroglucan: the repeat unit, as presented in Fig. 1, consists of linearly linked $\beta$-(1$3)$-D-glucose residues with one every three laterally substituted with a $\beta$-(1-6)-D-glucose residue (Rau 2005).

Schizophyllan has been used for skin care as a skin antiaging and healing agent (Kim et al. 1999). Schizophyllan is an active ingredient that can increase skin cell proliferation, reduce skin irritation, and also aid in recovery after sunburn (Kim et al. 2000).

Much research has been conducted on schizophyllan as a pharmaceutical compound (Kraus 1990; Bohn and BeMiller 1995). Thanks to its immune-stimulating functions, schizophyllan was claimed as antivirus agent (Shigero et al. 1989; Hagiwara and Kikuchi 1992), as prevention against fish diseases (Yano 1990), and as an immune enhancer for vaccines (Honma 1994). 


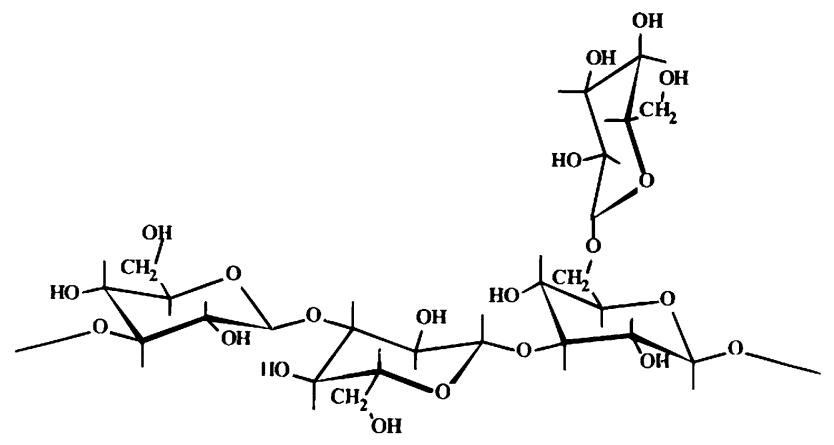

Fig. 1 Molecular structure of SPG

Schizophyllan has also been used as an immunotherapeutic agent for cancer treatment in Japan since 1986. It is used in conjunction with chemotherapy or radiotherapy. Clinical studies have shown that the administration of schizophyllan, along with antineoplastic drugs, prolongs the lives of patients with lung, gastric or uterine cancers (Furue 1987; Yoshio et al. 1992; Kimura et al. 1994).

The potential application of schizophyllan in the petroleum industry has not been well investigated (Ogezi et al. 2014). This paper studies the rheology of schizophyllan under high salinity and high temperature conditions. A field pilot was carried out to verify the effectiveness of schizophyllan in the enhancement of oil recovery.

\section{Materials and method}

Schizophyllan was provided by Tianli Chemical Company in China. Other chemicals, such as $\mathrm{NaCl}$ and $\mathrm{CaCl}_{2}$ were purchased from local suppliers. A sandstone core sample from a local field was used in flooding experiments, with porosity of $24 \%$ and permeability of $1900 \mathrm{mD}$. A crude oil sample was also taken from the local field, with a specific gravity of 0.9 and viscosity of $35 \mathrm{cP}$ at standard conditions.

High salinity brine was prepared by mixing $\mathrm{NaCl}$ and $\mathrm{CaCl}_{2}$ into distilled water. The concentration of $\mathrm{NaCl}$ and $\mathrm{CaCl}_{2}$ was 130 and $50 \mathrm{~g} / \mathrm{L}$, respectively. The viscosity of Schizophyllan in brine was measured with a rotational viscometer at varied shear rates. To test SPG's thermal stability, the viscosity measurements were conducted at temperatures up to $120^{\circ} \mathrm{C}$.

Core flooding experiments were carried out to evaluate the resistance factor (RF), residual resistance factor (RRF), and oil recovery. The resistance factor is defined as the ratio of the mobility of brine to that of polymer fluid, as given in Eq. 1 (Sheng 2010). A fluid mobility is defined as its relative permeability divided by its viscosity. The residual resistance factor is defined as the ratio of rock permeability to brine before polymer flooding and after polymer flooding, as shown in Eq. 2 (Sheng 2010).
$\mathrm{RF}=\frac{\lambda w}{\lambda p}$

$\lambda w$ : mobility of brine

$\lambda p$ : mobility of polymer fluid.

$\mathrm{RRF}=\frac{K_{b}}{K_{a}}$

$K_{b}$ : rock permeability to brine before polymer injection. $K_{a}$ : rock permeability to brine after polymer injection.

For the RF tests, the core was flooded with brine at varied injection rates, followed by polymer injection. For the RRF tests, the core was first flooded with brine, followed by polymer fluid, and chased by brine injection at last. The pressure loss across core was continuously monitored. RF and RRF values are calculated based on the pressure loss data.

Core flooding tests followed standard recovery test procedures (Gao and Bellout 2013). The first core experiment was to establish the oil recovery by water flooding. The core was first saturated with brine, and then flooded with crude oil to irreducible water saturation (Swi). Afterwards, brine was injected to reach residual oil saturation (Sor). The oil recovery by water flooding is obtained by measuring the volume of displaced oil.

The second core flooding test was carried out to evaluate the capability of SPG to improve oil recovery. The experiment followed the same procedures. The core was first saturated with brine, and then flooded to Swi with crude oil. Afterwards, $1 \mathrm{~g} / \mathrm{L}$ SPG solution was injected till residual oil saturation and oil recovery was obtained. The test matrix is summarized in Table 1.

\section{Experimental results}

As the primary requirement for EOR, polymers must maintain high viscosity under high salinity and high temperature. The base brine contained $130 \mathrm{~g} / \mathrm{L} \mathrm{NaCl}$, plus $50 \mathrm{~g} / \mathrm{L} \mathrm{CaCl}{ }_{2}$. This composition of brine was chosen to match the salinity of formation water in future pilot test. Schizophyllan was mixed into base brine, and the viscosity was measured with a shearing-type viscometer at $55^{\circ} \mathrm{C}$. The test data are presented in Fig. 2.

According to test data, SPG solution demonstrates high viscosity in high salinity brine. The typical shear rate in reservoir rock is around 10/s. Under such shear rate, SPG solution achieved viscosity of $36 \mathrm{cP}$ at a concentration of $0.5 \mathrm{~g} / \mathrm{L}$. The viscosity further increased to $65 \mathrm{cP}$ and $102 \mathrm{cP}$ at higher concentration of schizophyllan. However, under similar conditions, the viscosity of HPAM solution is much lower than that of SPG, as seen in Fig. 2. 
Table 1 Summary of Test Matrix

\begin{tabular}{llllll}
\hline $\begin{array}{l}\text { Test } \\
\text { Number }\end{array}$ & $\begin{array}{l}\text { Objective } \\
\text { of test }\end{array}$ & $\begin{array}{l}\text { Test Temperature } \\
\left({ }^{\circ} \mathrm{C}\right)\end{array}$ & $\begin{array}{l}\text { SPG Concentration } \\
(\mathrm{g} / \mathrm{L})\end{array}$ & $\begin{array}{l}\mathrm{NaCl} \text { Concentration } \\
(\mathrm{g} / \mathrm{L})\end{array}$ & $\begin{array}{l}\mathrm{CaCl} \mathrm{C}_{2} \text { Concentration } \\
(\mathrm{g} / \mathrm{L})\end{array}$ \\
\hline 1 & Rheology & 55 & $0.5 ; 1.0 ; 1.5$ & 130 & 50 \\
2 & Thermal stability & $30-120$ & 1.0 & 130 & 50 \\
3 & Resistance factor & 55 & $0.5 ; 1.0 ; 1.5$ & 130 & 50 \\
4 & Oil recovery & 55 & 1.0 & 130 & 50 \\
\hline
\end{tabular}

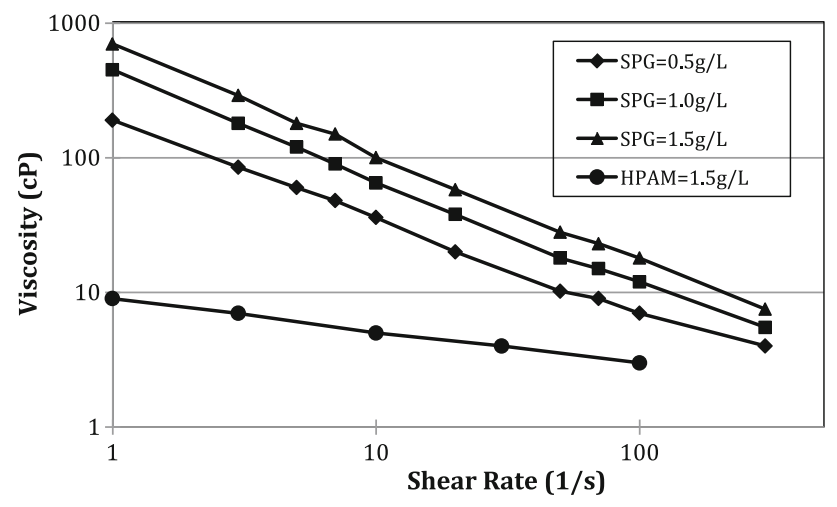

Fig. 2 Viscosity of schizophyllan in brine

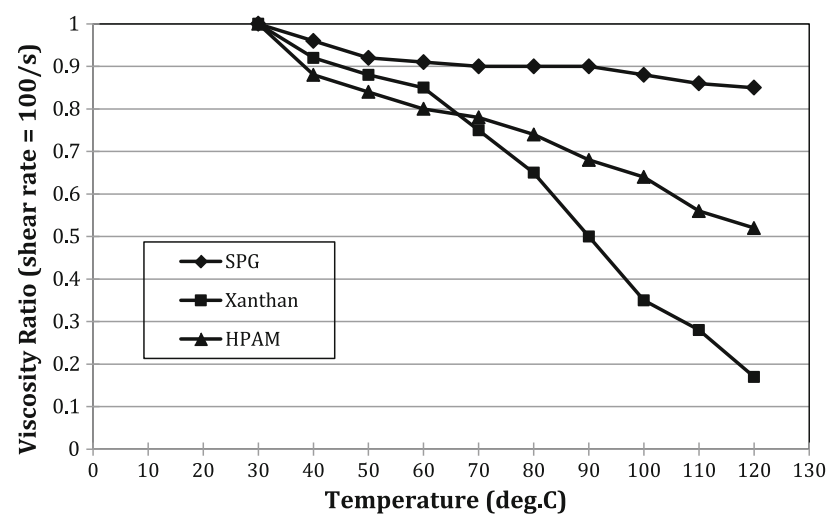

Fig. 3 Viscosity of Schizophyllan under high temperature

The SPG solution free of oxygen was heated to $120^{\circ} \mathrm{C}$ in HTHP viscometer, and the viscosity was measured. The viscosity of SPG was also compared with Xanthan and HPAM. As seen in Fig. 3, all polymers performed well at low temperatures. The viscosity of schizophyllan declined mildly when temperature increased, while Xanthan and HPAM degraded much more severely.

For instance, SPG at $90{ }^{\circ} \mathrm{C}$ still maintained $90 \%$ of its original viscosity at $30{ }^{\circ} \mathrm{C}$. But, HPAM and Xanthan at $90{ }^{\circ} \mathrm{C}$ lost 32 and $50 \%$ of their original viscosity, respectively. Long-term tests were also conducted on SPG at $90{ }^{\circ} \mathrm{C}$. It was discovered the viscosity of SPG did not decline significantly after 2 months of testing.

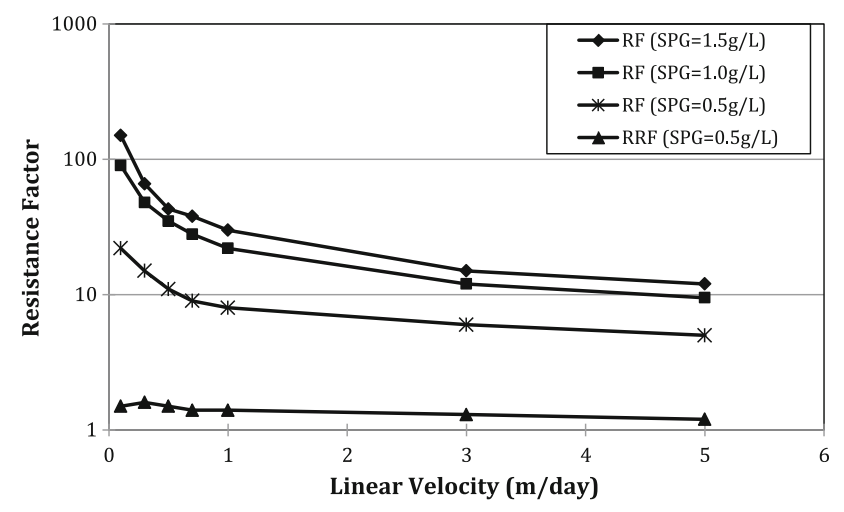

Fig. 4 Resistance factor for schizophyllan in core flooding tests

The heat resistant property of SPG is possibly attributed to its complex structure. Previous study revealed the triple helix molecular structure of SPG (Rau 2005). On the other hand, Xanthan gum possesses a double helix structure, while HPAM is a long single chain. The relatively simple structure of Xanthan and HPAM make them more vulnerable to heat and shear. More research needs to be conducted to understand the mechanism behind.

The test results on resistance factor are presented in Fig. 4. The injection of schizophyllan obviously increased the pressure drop across the rock core. However, the resistance factor quickly declined at higher injection velocity. On the other hand, the residual resistance factor remained low under both low and high fluid velocity. This indicates that for the field trial, the injection pressure during polymer injection should increase. However, the water flooding following polymer injection should not encounter excessive injection pressure.

The recovery tests reveal water flooding leads to $65 \%$ oil recovery after injection of five pore volume of brine injection. While for the recovery test with SPG solution, steady state was achieved after three pore volumes of injection, and oil recovery reached $75 \%$ after four pore volumes of SPG solution has been injected. This concludes that SPG not only improves oil recovery, but also speeds up the recovery process. 
Table 2 Reservoir properties for the field trial

\begin{tabular}{ll}
\hline Average reservoir porosity & $25 \%$ \\
Average reservoir permeability & $2000 \mathrm{mD}$ \\
Average reservoir temperature & $54{ }^{\circ} \mathrm{C}$ \\
Average reservoir thickness & $15.25 \mathrm{~m} / 50 \mathrm{ft}$ \\
Oil specific gravity & 0.906 \\
API oil gravity & 24.7 \\
Live oil viscosity & $29 \mathrm{cP}$ \\
Gas oil ration & $12 \mathrm{~m}^{3} / \mathrm{m}^{3}$ \\
\hline
\end{tabular}

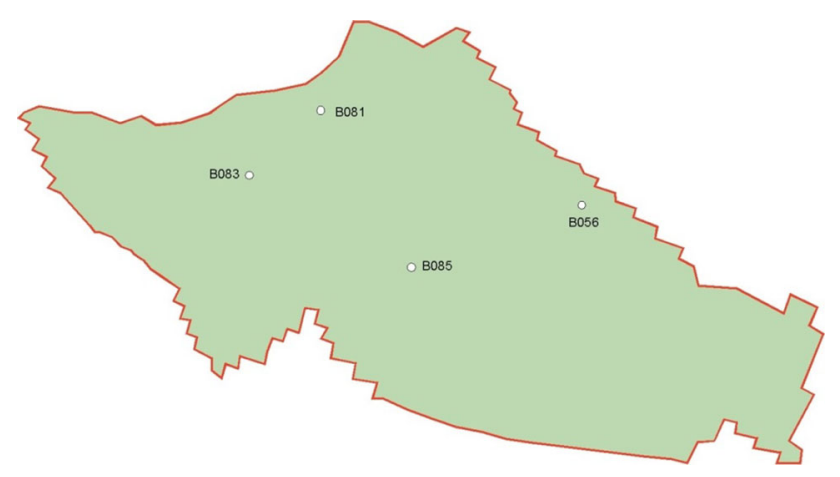

Fig. 5 Location map for the pilot area

\section{Field trial}

To validate the effectiveness of SPG in the field, a field trial was initiated in the Bockstedt oilfield in Northern Germany. The field was discovered in 1953 with OOIP of 6.4 million tons (or 45 million barrels) of crude oil. Production began in 1954, and peaked in 1962 at 3730 BOPD (barrels oil per day). Current field production is around 500 BOPD, while the water cut has reached $95 \%$. So far 87 production wells and injection wells have been drilled, but most of them have been plugged and abandoned in late 1990s.

The sandstone reservoir is buried at 1097-1311 m (3600-4300 ft), with an average thickness of $15.25 \mathrm{~m} \mathrm{(50}$ $\mathrm{ft}$ ) in the pilot area. The key reservoir properties and crude oil properties are given in Table 2 (Leonhardt et al. 2014). The reservoir has high porosity and permeability, while the oil is medium heavy. The formation water has very high salinity, including $132 \mathrm{~g} / \mathrm{L} \mathrm{NaCl}$, plus $42.5 \mathrm{~g} / \mathrm{L} \mathrm{CaCl}_{2}$, and $10.5 \mathrm{~g} / \mathrm{L} \mathrm{MgCl}_{2}$.

The pilot area, as shown in Fig. 5, employs one injection well (B083) and three production wells (B056, B081 and $\mathrm{B} 083)$. The distances between injection well and productions wells range from 230, 460 to $850 \mathrm{ft}$. Biopolymer mother fluid was produced at a nearby chemical plant then transported to site by tanks. The mother fluid was mixed with biocide and brine by a mixer on site. The polymer fluid was then filtered and injected into well B083.

The pilot block received water flooding since 2011 . The injection of polymer was initiated in early 2014 at a rate of $135 \mathrm{~m}^{3} /$ day (or 850BPD). By the end of 2013, over $45000 \mathrm{~m}^{3}$ (283,000 barrels) of polymer solution had been injected. Based on field sampling, the biocide effectively prevented biodegradation. Injectivity declined mildly during polymer flooding. Based on fluid sampling, the in situ polymer viscosity was maintained around $25 \mathrm{cP}$. During polymer injection, downhole injection pressure increased by $4.5 \mathrm{MPa}$ (or $650 \mathrm{psi}$ ) from previous water injection.

The biopolymer solution has reached the nearest production well (B081). The oil production rate at well B081 increased by more than $20 \%$, compare with the previous rate under water flooding. The other two production wells have not demonstrated changes in production, since the injected polymer has not yet reached these two wells. More field results will be reported in the near future.

\section{Conclusions}

(1) Based on experimental test, schizophyllan maintains good viscosity under high salinity and high temperature. (2) Core flooding test revealed reasonable residual resistance factor and good oil recovery by injection of schizophyllan solution. (3) Field pilot confirmed good injectivity and early results in improved oil production.

Acknowledgments The author is thankful for the research fund provided by Shandong Province government through Taishan Scholar program.

Open Access This article is distributed under the terms of the Creative Commons Attribution 4.0 International License (http:// creativecommons.org/licenses/by/4.0/), which permits unrestricted use, distribution, and reproduction in any medium, provided you give appropriate credit to the original author(s) and the source, provide a link to the Creative Commons license, and indicate if changes were made.

\section{References}

Bohn JA, BeMiller JA (1995) 1,3- $\beta$-d-glucans as biological response modifiers: a review of structure-functional activity relationships. Carbohydr Polym 28:3-14

Furue H (1987) Biological characteristics and clinical effect of schizophyllan. Drugs Today 23:335-346

Gao C (2011) Scientific research and field applications of polymer flood in heavy oil recovery. J Petrol Exploration Prod Technol 3(1):65-70

Gao C (2013) Viscosity of partially hydrolyzed polyacrylamide under shearing and heat. J Petrol Exploration Prod Technol 3(3):203-206 
Gao C (2014) Empirical correlations for viscosity of partially hydrolyzed Polyacrylamide. J Petrol Exploration Prod Technol 4(2):209-213

Gao C (2015) Potential of welan gum to enhance oil recovery. J Petrol Exploration Prod Technol. doi:10.1007/s13202-014-0114-1

Gao C, Bellout A (2013) An evaluation for two bacillus strains in improving oil recovery in carbonate reservoirs. Pet Sci Technol 31(11): 1168-1174

Gao C, Shi J, Zhao F (2014) Successful polymer flooding and surfactant-polymer flooding projects at Shengli Oilfield from 1992 to 2012. J Petrol Exploration Prod Technol 4(1):1-8

Hagiwara K, Kikuchi M (1992) Anti-virus agent, JP 4054124

Honma M (1994) Immune effect enhancer for vaccine, JP 6172217

Kim JS, Kim MS, Lee DC, Lee SG, So S, Kim YT, Park BH, Park KM (1999) Production of beta-1,6-branched beta-1,3-glucan useful as skin anti-aging, depigmenting and healing agent, JP 11313667

Kim MS, Park KM, Chang I-S, Kang HH, Sim Y-C (2000) $\beta-1,6-$ branched $\beta-1,3$-glucans in skin care. Allured's Cosmetic Toiletries Magazine 115:79-86

Kimura Y, Tojima H, Fukase S, Takeda K (1994) Clinical evaluation of schizophyllan as assistant immunotherapy. Otolaryngology (Stockholm) 511:192-195

Kraus J (1990) Biopolymere mit antitumoraler und immunmodulierender Wirkung. Pharm Unserer Zeit 19:157-164

Lake L (2010) Enhanced Oil Recovery. Society of Petroleum Engineers, Richardson Texas USA, pp 1-211
Leonhardt B, Ernst B, Reimann S (2014) Field testing schizophyllan: results of first year, SPE 169032 presented at improved oil recovery symposium. Tulsa Oklahoma 12:16

Morel D, Vert M, Bouger Y (2010) First polymer injection in deep offshore field Angola, SPE 135735 presented at the Annual Technical Conference and Exhibition, 19-22 Sept, Florence, Italy

Ogezi O, Strobel J, Egbuniwe D (2014) Operational aspects of a biopolymer flood in a mature oilfield, SPE 169158 presented at improved oil recovery symposium. Tulsa Oklahoma 12:16

Rau U (2005) Schizophyllan. Biopolymers Online. 6

Sheng J (2010) Modern Chemical Enhanced Oil Recovery: Theory and Practice. Gulf Professional Publishing, Oxford UK, pp 101-111

Shigero M, Fisamu S, Wataru I (1989) Anti-aids virus agent. JP 1287031

Xu L, Xu G, Yu L, Dong M (2014) The displacement efficiency and rheology of welan gum for enhanced oil recovery. Polym Adv Technol 25:1122-1129

Yano T (1990) Preventive for fish disease comprising water-soluble glucan, JP 2218615

Yoshio S, Katsuhiko H, Kazumasa M (1992) Augmenting the effect of schizophyllan on the immunofunction of regional lymph nodes in cervical cancer. Cancer 69:1188-1194 